DOI https://doi.org/10.36059/978-966-397-176-6/21-41

\title{
THE FORMATION OF INFORMATION \\ AND COMMUNICATION CULTURE OF THE FUTURE TEACHERS OF PHYSICS IN THE PROCESS OF PROFESSIONAL TRAINING
}

\section{Ivanytskyi O. I.}

\section{INTRODUCTION}

The intensive development of the global information space and its components on the territory of our state necessitated a significant modernization of the format of a professional activity of physics teachers. The main features of this new format is the possession of the teacher of physics algorithms of search and processing of various types of information and its representation in the form of an educational product of physics, the ability to navigate in a variety of modern educational computer programs in physics and it is advisable to apply in the educational process, independently apply information and educational technologies in the educational process in physics, create and develop information space and use it to teach students physics. It is included in the system of meta-knowledge and meta-knowledge of the teacher of physics, forming one of the most important components of the culture of modern human and society-information culture. However, on the way of the information culture formation of the future teacher of physics there are contradictions between requirements of modern educational process on creation of the information environment in each higher educational institution and absence at a considerable number of teachers of experience and necessary skills to use of such environment in educational process, between the requirement of professional activity of teachers of physics concerning continuous expansion and updating of skills to use in the information systems for effective training of students in physics and unorganized character of mastering by students of skills of using these systems in higher education. These contradictions generate a problem of formation of information culture of future physics teachers in 
the conditions of specially created information and educational environment.

The basis for overcoming these contradictions and shortcomings are laid in scientific works devoted to the disclosure of the essence of the phenomenon of information culture from the standpoint of philosophy (N. Jincharadze), pedagogy (S. Antonov, N. Volkov, N. Gendina, N. Zhaldak, T. Koval, N. Morse, Yu. Pervin, S. Sysoeva, V. Fedorov, V. Kharchenko), sociology (V. Kogan, V. Ukhanov). The analysis of available scientific works allowed to allocate information culture as an integral part of basic culture of the person which allows to participate effectively in all types of work with information: its reception, accumulation, coding and processing, and also in creation on this basis qualitatively new information, its transfer and practical use.

Ways of pedagogical formation of information culture in various subjects of training is put in the scientific works devoted to formation of information culture of pupils of General educational institutions (A. Goncharova, I. Vetrova, A. Vitukhnovska, S. Malyarchuk, A. Rakitina, A. Yasinsky, etc.), problems of formation of separate components of information culture of future teachers (V. Gritsenko, L. Konoshevsky, I. Pustynnikova, A. Stolyarovska, S. Sysoeva, etc.), in particular, future teachers of physics (P. Atamanchuk, T. Gordienko, V. Zabolotny, V. Sergienko, V. sharko, etc.).

At the same time, the emphasis in the methodical preparation of the future physics teacher on the formation of knowledge, skills and computer skills, the use of computer programs in the educational process in no way can be attributed to the background of the formation of his communicative competence. Therefore, the article considers the method of formation of communicative competence as a necessary component of the information culture of the teacher of physics

Trends in the development of modern secondary and higher schools indicate that less time is given to the school students and students of pedagogical educational institutions for monological and dialogical speech, which is replaced by test methods and a variety of options for distance learning. Therefore, the problem of formation of communicative competence of the future teacher of physics becomes more acute. The refusal of a significant proportion of applicants to choose natural, in 
particular physical, and many engineering specialties, despite the wide range of reasons for this phenomenon, is not least determined by the fact that many teachers of natural subjects do not have a sufficient level of communicative competence, are not ready to flexibly manage the process of interaction during training and education, apply communication technologies, promote mutual understanding, etc. From communicative competence of future teachers of physics depends on favorable morallypsychological climate, humanism and democratic communication, the effectiveness of networking, communication efficiency, in terms of solving problems, satisfaction of teachers and students with their work, the attitude of the students towards physics as a school subject.

Various aspects of competence of specialists of different professions are investigated in the works of T. O. Babkin, R. burns, V. Zabolotny, N. Masyukova, L. Mitina, P. Samoylenko, O. Sergeev, I. Sigov, O. Smirnova, V. Strelnikov, M. Choshanov and others. Many researchers considered different component composition of competence. This article is based on the structure of competence presented in the studies of I. Zimnaya:

1) motivational aspect of competence (readiness to demonstrate the competence);

2) cognitive aspect of competence (knowledge of competence content);

3) behavioral aspect of competence (experience of competence in a variety of standard and non-standard situations);

4) value-semantic aspect of competence (relation to the content of competence and the object of its application);

5) emotional-volitional aspect of competence (emotional-volitional regulation of the process and result of the manifestation of competence) ${ }^{1}$.

The solution of the problem of formation of communicative competence of future teachers of physics was based on the competent

1 Зимняя И. А. Ключевые компетентности как результативно-целевая основа компетентностного подхода в образовании. Москва : Исследовательский центр проблем качества подготовки специалистов, 2004. С. 25-26. 
approach to the professional training of specialists and the theory of contextual training of A. Verbitsky ${ }^{2}$.

\section{Preparation of the future physics teacher for realization of information function}

The function (lat. functio-execution, implementation) is the external manifestation of the properties of an object in a certain system of relations ${ }^{3}$. In this context, the personal characteristics of the physics teacher, reflecting his social position, certain natural abilities and properties, become relevant. It is refracted through the character of the teacher, his individual psychological characteristics of the performance of professional functions acquires either completeness and content, or formalism and mediocrity. In the pedagogical literature ${ }^{4}$, the following functions of the teacher are distinguished: communicative, information, mobilization, design, organizational, orientation, developing and gnostic. Naturally, all these functions are reflected in the activities of the teacher of physics, but their share in the educational process in physics is different. One of the most important is the information function of the physics teacher.

The importance of the information function of the teacher of physics in the general didactic plan depends on the fact that all training and education are essentially to some extent based on information processes. $\mathrm{We}$, based on the work ${ }^{5}$, think that this function is in the message to students in the process of teaching physics meaningful, logically coherent, saturated with vivid examples of information. Information function provides real psychological contact with students, the process of knowledge, mutual understanding, exchange of material and spiritual values; forms a positive motivation for success in educational activities and self-education, in the formation of personality. The emergence of a wide range of educational computer programs, the development of multimedia and Internet-network with its unlimited information resources raises the problem of modernization of the training of the

2 Вербицкий А. А. Концепция знаково-контекстного обучения в вузе. Bonpocы психологии. 1987. № 5. С. 31-39; Заброцький М. М., Максименко С. Д. Комунікативна компетентність учителя: сутність і шляхи формування Житомир: Волинь, 200032 с.

${ }^{3}$ Философский словарь / Под ред. М. М. Розенталя. М.: Изд. 3-е Политиздат, 1975. С. 448.

4 Бобух Л., Сиволап Т. Закономірності організації і практика управління інформаційним простором. Київ : Вища школа. 2008. № 9. С. 47-48.

${ }^{5}$ Там само. 
future teacher of physics to implement the information function in professional activities.

The researches of N. Kuzmina, Yu. Kulyutkin, G. Sukhobsko, A. Shcherbakov and others are devoted to the content and structure of the teacher's functions. According to N. Kuzmina, the main professional functions of the teacher are the constructive, gnostic, organizational and communicative $^{6}$. A completely different classification of professional functions of the teacher offers psychologist O. Shcherbakov. There are two large groups: a) General labor, which includes those functions that are investigated by N. Kuzmina, gnostic replaced by research and b) actually pedagogical. The meaning of this classification is that the first group of functions can be attributed not only to the teaching profession, but also to many others. Interest approach and judgment have the scientists Kulyutkin Y. and G. Suchomski about the functional roles of the teacher. In the work at different stages of educational process the teacher acts as the practical executor of own plans, then as the methodist and the researcher. Scientists rightly note that the same teacher, depending on the stage of educational work occurs in one, then in another, then in the third function.

Various aspects of formation of professional functions of the future teacher of physics are investigated by P. Atamanchuk, S. Velichkom, S. Goncharenko, A. Sergeev, V. Sergienko, S. Sisoyevoyu, V. Sharko, etc. Separate aspects of this problem are considered in dissertation researches (N. Volkova, V. Zabolotny, Is. Komarevtsev, A. Nadabi, M. Prokof'ev, N. Sosnitskaia, N. Stuczynski, V. Sharko, etc.).

The specifics of the work on the preparation of the future teacher of physics should be considered in the professional competence that is embodied in the formation of the above-mentioned basic functions of the teacher of physics. Therefore, we have assumed that the weighted proportional selection of pedagogical influence in the study of physics teaching methods courses and for testing of each function will allow pattern emergentness the system of training of future teacher of physics (which manifests itself in a multiplicity of pedagogical influence in training) and strengthen basic and professional training of future teacher of physics.

\footnotetext{
${ }^{6}$ Кузьмина Н. В. Предмет акмеологии. Санкт-Перебург : Питер, 1995. 158 с.
} 
The implementation of this idea was based on the determination of the relative importance of basic functions from the point of view of teachers of physics. To do this, respondents were asked to estimate the value of each of the eight main functions by distributing 40 conditional points between them. Based on the probability level $\Theta=0.95$ and the absolute error $\alpha=0.05$, the expert method established a frequency of 0.8 prevalence estimates of information, communication, orientation and developmental functions. Then, under these conditions, the sample size was 246 teachers. On the basis of stratified selection of objects of sampling (executions were groups of teachers of physics depending on the general length of service till 3 years; from 3 till 8 years; from 9 till 15 years; more than 15 years of experience as the teacher of physics) in sample it was selected proportionally to the named distribution respectively on 62 teachers of physics. Each sample group that matched the execution consisted by random selection. Among the selected physics teachers, a survey was conducted to identify the relative importance of the main functions of a physics teacher in the process of teaching physics. The results are presented in table 1 .

Table 1

\section{Assessment of the importance of basic functions}

by teachers of physics

\begin{tabular}{|c|c|c|c|c|c|c|}
\hline № & $\begin{array}{c}\text { The name of } \\
\text { function of } \\
\text { physics teacher }\end{array}$ & $\begin{array}{c}\text { 1st group } \\
\text { (till 3 } \\
\text { years); } \\
\text { \% within } \\
\text { group/ } \\
\text { general\% }\end{array}$ & $\begin{array}{c}\text { 2nd } \\
\text { group } \\
\text { from 3 } \\
\text { to 8 } \\
\text { years); } \\
\text { \% within } \\
\text { group/ } \\
\text { general\% }\end{array}$ & $\begin{array}{c}\text { 3rd } \\
\text { group } \\
\text { from 9 } \\
\text { to 15 } \\
\text { years); } \\
\text { within } \\
\text { group/ } \\
\text { general } \\
\text { \% }\end{array}$ & $\begin{array}{c}\text { 4th } \\
\text { group } \\
\text { (more } \\
\text { than 15 } \\
\text { years); } \\
\% \text { within } \\
\text { group/ } \\
\text { general } \\
\%\end{array}$ & $\begin{array}{c}\text { The } \\
\text { meaning of } \\
\text { functions } \\
\text { in the } \\
\text { educational } \\
\text { progess; } \\
\%\end{array}$ \\
\hline 1 & Informative & $46,2 / 12$ & $44,1 / 10,4$ & $34,4 / 8,4$ & $31,8 / 7,9$ & 38,7 \\
\hline 2 & Oriental & $16,9 / 4,2$ & $15,3 / 3,8$ & $6,6 / 1,7$ & $7,4 / 1,8$ & 11,4 \\
\hline 3 & Communicative & $10,8 / 2,7$ & $11,9 / 3$ & $16,4 / 4,1$ & $16,1 / 4$ & 13,8 \\
\hline 4 & Developing & $7,7 / 1,9$ & $8,5 / 2,1$ & $13,1 / 3,3$ & $13,8 / 3,4$ & 10,7 \\
\hline 5 & Organizational & $6,1 / 1,5$ & $6,8 / 1,7$ & $14,8 / 3,7$ & $15,1 / 3,7$ & 10,6 \\
\hline 6 & Projective & $4,6 / 1,2$ & $6,8 / 1,7$ & $6,6 / 1,7$ & $7,0 / 1,8$ & 6,3 \\
\hline 7 & Mobilizational & $4,6 / 1,2$ & $4,4 / 1,1$ & $4,8 / 1,2$ & $4,9 / 1,2$ & 4,7 \\
\hline 8 & Gnostic & $3,1 / 0,8$ & $4,4 / 1,1$ & $3,3 / 0,8$ & $3,9 / 0,9$ & 3,6 \\
\hline
\end{tabular}


As can be seen from table 1, the assumption of the dominant role of the first four technological functions in the activity of the physics teacher was confirmed, but a deeper analysis of the experimental data revealed some significant points. First of all, it concerns the significant differences in the evaluation of the functions of the physics teacher by different executions. Thus, the information function is evaluated much higher by novice teachers and the importance of such important functions as organizational, projective and developmental is humiliated. The comparison of the evaluation of these functions by the first and the last two groups is indicative, as is the serious General underestimation by all executions of the specific gravity of the projective function. However, the consensus for the survey is the statement of the dominant role of the information function in the pedagogical activity of the teacher of physics.

The rapid development of computer technology and multimedia teaching tools have led to a significant impact on the implementation of the information function of the teacher, putting forward new requirements for professional knowledge, skills and competencies of the modern teacher of physics ${ }^{7}$. The informative function of the teacher in case of complex application of means of multimedia, educational computer programs, web-technologies and computer networks of various types can be realized both directly and indirectly linked with effects on cognitive process during key stages of learning: sensory perception of the material, its understanding and memorization. The partial transfer of the information function of the teacher in the classroom to multimedia allows to significantly expand the range of information sources and strengthen their psychological impact on students due to specific educational visualizations, the capabilities of computer equipment and multimedia. The implementation of multimedia part of the information function of the teacher of physics creates additional opportunities for him to establish contact with students in the implementation of pedagogical communication in the classroom. Yourself multimedia tools used to perform information functions are considered as human-made resources that are either originally designed to facilitate actions within the structure

\footnotetext{
${ }^{7}$ Іваницький O.I. Сучасні технології навчання фізики у середній школі: монографія. Запоріжжя : Прем’єр, 2001. 266 с.
} 
of learning activities, or selected for these purposes from the number of objects with different purpose.

Computer didactic components of the information and educational environment allow to organize contextual learning, in which the process of implementing the information function of the teacher is consistently modeled. An important factor in creating an information and educational environment in the context of the implementation of the information function of a physics teacher is a specific knowledge base containing video clips of real physics lessons, training computer programs, collections of thematic presentations on the course of high school physics, video lectures on physics, links to various educational sites. Thus, the future professional activity is presented in the form of a model of the teacher of physics: a description of the system of its main professional functions, problems and tasks. With a contextual approach, the information received by students from the knowledge base is a certain parameter of the future, i.e. the student is given the opportunity to really imagine where and how it can be used. It is in this way that the information that is offered for assimilation quickly acquires a personal meaning for the future physics teacher and can be effectively used to implement the information function of the physics teacher.

In the organization of educational and cognitive activity of students, the functions of the teacher are primarily in the selection, presentation, dosing of information. The choice of the subject of educational and cognitive activity is largely limited by the requirements of the program in physics and the content of textbooks. However, the teacher of physics has the right to choose the sequence of presentation of the theme of the story, the use of certain means of training at his discretion. In any case, the important point here is the level of possession of the material, which can demonstrate the teacher of physics. The quality of its explanation, content, logic of message construction, etc. depend on it ${ }^{8}$. Well knowing the content of his subject, the teacher, realizing the information function, should be able to carry out modeling of the presentation of educational

\footnotetext{
${ }^{8}$ Іваницький О.І. Сучасні технології навчання фізики у середній школі: монографія. Запоріжжя : Прем'єр, 2001. 266 с.; Чернилевский Д.В. Дидактические технологии в высшей школе: учеб. пособие для вузов. Москва : ЮНИТИ-ДАНА, 2002. 437 с.
} 
material in physics, which requires special training in the process of professional training of the future teacher of physics. The task is to convey the full content of the school physics course and the concept of physics as a science of nature for a minimum of information.

Familiarization of students with new information using multimedia makes significant demands on its quality. It should be clear, encourage understanding and systematization of knowledge.

The process of preparing future teachers of physics to implement the information function using computer didactic components of the information and educational environment occurs as a result of actionable activity based on the following principles:

* problems, involving the systematic construction of the content, forms, methods and means of education, the dependence of their structures on the logic of pedagogical activity of future teachers of physics;

* activity of the student, which uses knowledge of the theory and methodology of teaching physics to generate active methods and forms of education in order to form the ability to predict the professional situation and make informed independent decisions;

* modeling of the content and conditions of teaching activity of the teacher of physics in the process of formation of professional competences.

* The information function provides for the organization of individual, group and collective communication. The organization of individual communication contributes to a faster knowledge of the person, the impact on her consciousness, actions and actions, behavior, as well as their change and correction.

Let consider examples of methodological tasks aimed at preparing the future physics teacher to implement the information function, which are used in the process of studying the discipline «Theory and methodology of teaching physics», in particular, during a laboratory workshop on a school physical experiment.

Make a structural and logical diagram of the study of the topic „electromagnetic induction”. What are the positive aspects of this methodical approach to teaching physics? Submit this diagram as part of your presentation. 
The teacher should be able to present the material taking into account the level of preparation of students in the class. To simplify the situation, assume that we are talking about a deductive presentation in the form of a story of material for two different levels of training of students: for a strong student A and for an average in their training student B. With the same issue develop two texts narratives: for student A and for student B. As material for conversations you can take one of lessons themes „Electromagnetic induction”. Prepare multimedia accompaniment of the teacher's presentation for levels A and B.

Prepare an essay on „Decription of problems in physics in the study of electromagnetic induction (XI class)". What requirements should correspond to the tasks compiled by students? Select recommendations for teaching students how to compose tasks. Place this summary on your page in the social network, for example, in the Facebook.

The emergence of EMG induction many students explain the intersection of the conductor lines of force of the magnetic field. However, this condition is not always sufficient. For example, with the translational motion of a flat frame in a uniform magnetic field, the EMG of induction is zero, despite the fact that the sides of the frame intersect the lines of force. Point to specific deficiencies in the knowledge of high school graduates on this issue. Illustrate this task with computer drawings and animations. Find the necessary material with the help of Internet search engines.

In the process of the report, the teacher conducts a conversation with the student about the assimilation of this material, necessarily modeling educational situations.

In the theory and practice of teaching in higher education context on the basis of the developed three types of design situations: technology training dialogue; technology task approach; technology of simulation games. In the context of our study, we will elaborate on the educational dialogue. It was used by us in the process of teaching students in the thematic and conceptual part of the lesson, and later found its successful application by the students themselves during the pedagogical practice at the school. We consider dialogue not only as an active process of educational interaction, but also as a source of personal experience of the student as a factor of actualization of reflexive, critical function of the 
person and, in fact, as an important factor of preparation of the future teacher of physics to realization of information function. It is clear that the experience of dialogical communication accumulated gradually. We have seen this while working with bachelors, starting from the first year. Introduction to the situation of educational dialogue involves the presence of communicative experience, basic knowledge, installation on the self-narrative and the perception of other points of view; thinking through different versions of the plot and the development of storylines of the dialogue. So, during the dialogue on correctional and developmental training, students themselves formulated questions and problems that worried them: how to achieve a trusting style of communication, a sense of success for each student, to avoid discomfort in the modern physics lesson, how to identify the causes of the backlog in physics of a particular student, how to methodically competently and reasonably organize training in lessons of various types, so that students have confidence in their own abilities, and so on, tried to outline different options for solving contradictions and problems of the educational process in physics, based on basic knowledge of teaching methods in physics, pedagogy and psychology. In the process, the academic dialogue created an atmosphere of productive cooperation of students and teachers, and one result was the creation of the original cycle of integrative extra-curricular activities in physics for the students of VII-IX classes of the basic schools taking into account research done by students in preparation of course and diploma works on the methodology of teaching physics. A variant of the educational dialogue is online communication between the teacher and the student via the Internet, especially via Skype.

In the process of element-by-element analysis of their work, students developed personal and professional interest. And it is quite natural that during such educational dialogues cognitive actions included in the context of a social and personally significant situation acquired special motivation for the future physics teacher: instead of the traditional «remember and answer» there was a goal of real achievement, and the educational interaction was a cooperation that includes full immersion in the work, a very serious attitude to the feelings and emotions of others (students, pupils, teachers, university teachers), methodological 
reflection. It is important that with such an organization of educational dialogues spontaneously future physics teacher prepares for pedagogical activity in the information and educational environment.

\section{Methods of formation of future teachers of physics communicative competence}

In researches of different authors communicative competence is considered as:

- competence in communication: oral, written, dialogue, monologue, perception of the text; knowledge and observance of traditions, ritual, etiquette; cross-cultural communication; business correspondence; office work, business language; foreign language communication, communicative tasks, levels of impact on the recipient (I. Zimnaya);

- as a kind of integral characteristic of communication, in which the moral and ideological attitudes of the person, its general and professional orientation, the level of sociability are indirectly expressed (G. Zabrotsky, S. Maksimenko);

- the ability to achieve the desired results in communicating with people, while avoiding undesirable effects (I. Golovko);

- possession of collective professional activity and methods of professional communication, as the formation of social responsibility for the results of their activities (A. Markova).

According to these approaches of researchers, the essence of communicative competence can be represented as the ability and willingness to engage in various kinds of (nonverbal and verbal, oral and written) contacts to solve communicative problems (information transmission, negotiation, establishment and maintenance of contacts, etc.).

Building on the basic components of the structure of competence presented I. Simnow, and work by E. Filatova ${ }^{9}$, we have developed the following structure of communicative competence of the future teacher of physics:

\footnotetext{
${ }^{9}$ Филатова Е. В. Коммуникативная компетентность педагога: сущность и структура. Magister Dixit. № 1 (03). Март 2012. URL: md.islu.ru〉sites/md.islu.ru/files/rar/statya2 filatova.pdf
} 
- motivational and value component includes the readiness of the future teacher of physics to professional improvement, reflects a steady interest in innovation, information and communication technologies of teaching physics, the need for professional growth, the desire for selfdevelopment and self-realization;

- cognitive component contains knowledge of the essence of the content of communicative competence, reflects the knowledge of the essence and role of communicative competence associated with the knowledge of another person, includes the ability to effectively solve various problems arising in communication;

- operational-activity component contains the experience of the manifestations of communicative competence in a variety of standard and non-standard situations, the ability of a teacher to personalityoriented cooperation in the implementation of learning physics, the ability to maintain emotional balance, to prevent and resolve conflicts in a constructive way, the oratorical art, literate oral and written speech, a public presentation of the results of its work, the selection of the optimum forms and methods of self-presentation, ability to develop strategies, tactics and techniques of active interaction with people, to organize their joint activities to achieve certain socially significant goals, the ability to objectively assess the situation of interaction of subjects of the educational process, the ability to predict and justify the result of the effectiveness of interaction.

All three components of communicative competence are interrelated. The high level of communicative competence of the teacher of physics provides comprehensive development of all its components, greatful possession and application of communication techniques.

According to A. Verbitsky, contextual learning is a conceptual basis for the integration of educational, scientific and practical activities of students ${ }^{10}$. Highlighting the academic type of educational activity, quasiprofessional and educational activities as the main organizational forms of contextual learning, he emphasizes the special role in contextual learning is active forms and methods of learning.

${ }^{10}$ Вербицкий А. А. Концепция знаково-контекстного обучения в вузе. Boпросы психологии. 1987. № 5. С.31-39. 
The realization of the goal set in the study was based on the practical implementation of the principles of professional training of students, the embodiment of which was the design of the goals, content and technologies of integrative professional training of students from the standpoint of training future teachers of physics. This design was based on the praxeological principle of vocational training and contextual learning. It should be noted that praxiology - (from the Greek praktikos - active and logos - teaching) the science of norms and principles of effective and correct activity, productive work, productivity (justified by the Polish scientist T. Kotarbinsky) ${ }^{11}$. Praxeology is the effective functioning of vocational education on the basis of pragmatic priority in solving practical problems associated with the acquisition of future teachers of physics and determines the practical goal of integrative professional training of students:

* deep generalizing study of psychological and pedagogical bases of innovative technologies of education in secondary school;

* formation of a system of professional knowledge and skills of future physics teachers, which ensures the design and practical implementation of innovative teaching technologies;

* formation of technological thinking and development of technological abilities of students;

* development of cognitive interest in the subject teaching methodology, due to professional motivation contextual training of future teachers of natural and mathematical disciplines;

* strengthening of integrative and practical orientation of special professional training of future teachers of physics through the use of contextual tasks directly related to the future specialty of students;

* formation of the author's system of activity (ASA) of future teachers of physics.

The contextual approach to the professional training of future teachers of physics is a consistent combination of the traditional study of humanitarian and socio-economic disciplines with the integration of educational, scientific and pedagogical activity of students, which is an

\footnotetext{
11 
implementation of a dynamic model of their learning activities from the academic activities of the academic type (in lecture form) through quasiprofessional (role-playing and business games) and pedagogical (scientific research, pedagogical practice) to actually teaching.

The basic unit of activity of the student and the teacher in contextual training becomes not «a portion of information», and the pedagogical situation in all the subject and social uncertainty and inconsistency. The system of problematic pedagogical and methodological situations allows to develop a dialectically contradictory content of teaching in dynamics and thus provide objective prerequisites for the formation of theoretical and practical pedagogical thinking of the future teacher of physics. Determining the dialogical relations of students included in the situation, such content contributes to the formation of their communicative competence, since any subject action acquires the quality of an act that is characterized by a varying degree of personal responsibility, aimed at other people, obeys the accepted norms of relations and provides for the actions of other people. In actions of future teachers there is a social sense, social and pedagogical installations are formed.

In contextual training, the main emphasis is on the fact that the future teacher of physics already in higher education was put in conditions as close as possible to his future professional activity. That is why the educational process in the laboratory is based on the simulation of those elements of pedagogical work that students will have to perform as future teachers and on the integration of educational and professionalpractical activities of future specialists.

The contextual approach is implemented by performing two groups of tasks. The first group contains tasks related to the content and features of the implementation of the school physical experiment. The second group contains general methodological problems:

1. To carry out purposeful repetition of material of all subjects of a school course of physics.

2. Learn basic definition of quantities and laws of school physics course sequence and features of the presentation of the material in the textbooks for schools of different types; place this material in the school curriculum. 
3. To expand knowledge of educational and methodical literature on physics, to strengthen skills of work with it.

4. By modeling specific methodological situations to prepare students for practical activities in the role of a teacher of physics.

5. To form students' skills of monological and dialogical speech ${ }^{12}$.

The implementation of tasks $2,4,5$ is directly related to the formation of communicative competence.

It considers the formation of communicative competence of future teachers of physics in the performance of laboratory work from the school physical experiment on the example of laboratory work «electromagnetic induction».

Students should work out the main material of the topic according to the school curriculum. In the process of the report, the teacher conducts an interview with the student about the assimilation of this material, necessarily modeling educational situations.

In the theory and practice of teaching in higher education context on the basis of the developed three types of design situations: technology training dialogue; technology task approach; technology of simulation games $^{13}$. Let's do it in the form of educational dialogue. It was used by us in the process of teaching students in the thematic and conceptual part of the lesson, and later found its successful application by the students themselves during the pedagogical practice at the school. We consider dialogue not only as an active process of educational interaction, but also as a source of personal experience of the student as a factor of actualization of reflexive, critical function of personality and, in fact, as an important factor in the formation of communicative competence of the future teacher of physics. It is clear that the experience of dialogical communication accumulated gradually. We have seen this while working with bachelors, starting from the first year. The introduction of educational dialogue into the situation presupposes the presence of

\footnotetext{
12 Іваницький О. I. Професійна підготовка майбутнього вчителя фізики в умовах інформаційно-освітнього середовища: монографія. Запоріжжя : ЗНУ, 2014. 230 с.

13 Іваницький О. І., Ковальова В. М. Управління учителем фізики навчальною діяльністю учнів в умовах комп'ютерного навчання. Вісник Чернігівського державного педагогічного університету імені Т. Г. Шевченка. Серія: педагогічні науки: Збірник. Чернігів : ЧДПУ, 2010. С. 80-84
} 
communicative experience, basic knowledge, self-orientation and perception of other points of view; thinking through different versions of the plot and the development of dialogue storylines, which would be based on an innovative basis. So, during the dialogue on correctional and developmental training, students themselves formulated questions and problems that worried them: how to achieve a trusting style of communication, a sense of success for each student, to avoid discomfort in the modern physics lesson, how to identify the causes of lagging in physics of a particular student, how to methodically competently and reasonably organize training in lessons of various types so that students have confidence in their own abilities, and so on. In the process, the academic dialogue created an atmosphere of productive cooperation of students and teachers, and one result was the creation of the original cycle of integrative extra-curricular activities in physics for the students of VII-IX classes of the basic schools taking into account research done by students in preparation of course and diploma works on the methodology of teaching physics.

In the process of element-by-element analysis of their work, students developed personal and professional interest. And it is quite natural that during such educational dialogues cognitive actions included in the context of a social and personally significant situation acquired special motivation for the future physics teacher: instead of the traditional «remember and answer" there was a goal of real achievement, and the educational interaction was a cooperation that includes full immersion in the work, a very serious attitude to the feelings and emotions of others (students, teachers, University teachers), methodological reflection.

Context are the nature of the training tasks and objectives for the laboratory work. Among them, a special role is played by problemmethodical tasks of the context type on the methodology of teaching physics. This is a system of questions and tasks of scientific, and methodological nature of a specific topic of a school physics course, most of which models real pedagogical situations arising in the professional activity of a teacher. Protection of the laboratory component occurs during the lesson in the form of a dialogue with the teacher. At the same time, it is practiced in the process of checking the thematically- 
conceptual part of the presentation of the material by the student in the form of a monological broadcast focused on the student.

Significant opportunities for the formation of communicative competence have seminars, which are considered or issues of general methodology on the material of a certain educational topic in physics (for example, organizational forms of training in physics, control of students' knowledge in physics, planning of educational work of a physics teacher, etc.), or specific issues of studying a separate topic or section of a school physics course. The core of the seminar-business game is a fragment of a lesson of one type or another, implemented by students.

Contextual learning is carried out by designing physics lessons and methodological and psychological justification of projects from the perspective of students' perception. Characteristic of contextual learning at this stage is a comparative study of the experience of teachers of physics, the originality of innovative and traditional lessons. Individual forms of work of students and work in pairs and links prevail.

In the process of training future teachers of physics, the structure of students' educational activity should provide a certain algorithm for the formation of professional skills focused on the subject-subject nature of pedagogical interaction. Application of this algorithm assumes active activity of students as subjects of training, forecasting of development of educational situations. That is, we are talking about modeling the professional activities of future physics teachers, as a result of which educational information is used to perform specific contextual actions that affect the formation of communicative competence.

\section{CONCLUSIONS}

The relative importance of the main functions from the point of view of physics teachers and the importance of information and communication function was determined by questionnaires of respondents. Future professional activity is presented in the form of a model of the teacher of physics: a description of the system of its main professional functions, problems and tasks. The realization of the goal set in the study was based on the practical implementation of the principles of professional training of students, the embodiment of which was the design of the goals, content and technologies of integrative 
professional training of students from the standpoint of training future teachers of physics. This design was based on the praxeological principle of vocational training and contextual learning. The structure of communicative competence of the future teacher of physics, containing interrelated and interdependent motivational-value, cognitive and operational-activity components, is developed. The basic unit of activity of the student and the teacher in contextual training becomes not «a portion of information», and the pedagogical situation in all the subject and social uncertainty and inconsistency. The system of problematic pedagogical and methodological situations allows to develop a dialectically contradictory content of teaching in dynamics and thus provide objective prerequisites for the formation of theoretical and practical pedagogical thinking of the future teacher of physics. Determining the dialogical relations of students included in the situation, such content contributes to the formation of their communicative competence.

Three types of construction of educational situation are applied: technology of educational dialogue; technology of problem approach; technology of imitation games. Dialogue is considered not only as an active process of educational interaction, but also as a source of personal experience of the student as a factor of actualization of reflexive, critical function of personality and, in fact, as an important factor in the formation of communicative competence of the future teacher of physics.

\section{SUMMARY}

The article considers the method of formation of information and communication culture of future teachers of physics in the process of professional training. The relative importance of the basic functions from the point of view of teachers of physics and the importance of information and communication functions is determined. Future professional activity is presented in the form of a model of the teacher of physics: a description of the system of its main professional functions, problems and tasks. The structure of communicative competence of the future teacher of physics containing motivational-valuable, cognitive and operational-activity components is developed. 


\section{REFERENCES}

1. Бобух Л., Сиволап Т. Закономірності організації і практика управління інформаційним простором. Київ : Вища школа. 2008. № 9. С. 85-90.

2. Вербицкий А. А. Концепция знаково-контекстного обучения в вузе. Вопросы психологии. 1987. № 5. С.31-39.

3. Заброцький М. М., Максименко С. Д. Комунікативна компетентність учителя: сутність і шляхи формування Житомир: Волинь, 200032 с.

4. Зимняя И. А. Ключевые компетентности как результативноцелевая основа компетентностного подхода в образовании. Москва : Исследовательский центр проблем качества подготовки специалистов, 2004. 40 с.

5. Іваницький О. І. Інноваційні технології навчання фізики. Навчальний посібник. Запоріжжя : «Диво», 2007. 99 с.

6. Іваницький О. І. Професійна підготовка майбутнього вчителя фізики в умовах інформаційно-освітнього середовища: монографія. Запоріжжя : ЗНУ, 2014. 230 с.

7. Іваницький О. І., Ковальова В. М. Управління учителем фізики навчальною діяльністю учнів в умовах комп'ютерного навчання. Вісник Чернігівського державного педагогічного університету імені T. Г. Шевченка. Серія: педагогічні науки: Збірник. Чернігів : ЧДПУ, 2010. С. 80-84.

8. Іваницький О.I. Сучасні технології навчання фізики у середній школі: монографія. Запоріжжя : Прем’єр, 2001. 266 с.

9. Кузьмина Н. В. Предмет акмеологии. Санкт-Перебург : Питер, 1995. 158 с.

10.Новейший философский словарь. Праксеология. URL: http://dic.academic.ru/dic.nsf/dic_new_philosophy/

11. Филатова Е. В. Коммуникативная компетентность педагога: сущность и структура. Magister Dixit. № 1 (03). Март 2012. URL: md.islu.ru >sites/md.islu.ru/files/rar/statya2_ filatova.pdf

12. Философский словарь / Под ред. М. М. Розенталя. М.: Изд.3-е Политиздат, 1975. 496 с. 
13. Чернилевский Д. В. Дидактические технологии в высшей школе: учеб. пособие для вузов. Москва : ЮНИТИ-ДАНА, 2002. $437 \mathrm{c}$.

Information about the author:

\section{Ivanytskyi O. I.,}

Doctor of Educational Sciences, Professor,

Zaporizhzhia National University

66, Zhukovsky str., Zaporizhzhia, 69600, Ukraine 